\title{
Photodegradation of Mepronil
}

\author{
Takashi Yumita* and Izuru Yamamoto \\ Department of Agricultural Chemistry, Tokyo University of Agriculture, \\ Setagaya-ku, Tokyo 156, Japan
}

(Received October 17, 1981)

\begin{abstract}
Mepronil remaining after 80 days exposure to sunlight on the silica gel chromatoplate was 34.1 and $62.2 \%$ depending on the season (Sept. to Dec. and Nov. to Jan., respectively). The half-life is estimated as 36 days during Sept. to Dec. which was shortened to half when a photosensitizer, xanthone, was mixed with it. The degradation in water when irradiated with ultraviolet light was only $32.0 \%$ after $80 \mathrm{hr}$ at $30^{\circ} \mathrm{C}$. Twelve photoproducts were identified as 3'-(1-hydroxymethylethoxy)-2-methylbenzanilide; 3'-isopropoxy-2-hydroxymethylbenzanilide; 3 '-isopropoxy-4'-hydroxy-2-methylbenzanilide; 3 '-hydroxy-2-methylbenzanilide; 1-hydroxy-3-oxo-2-(3'-isopropoxyphenyl)isoindoline; 3'-(1-carboxyethoxy)2-methylbenzanilide; 3',4'-dihydroxy-2-methylbenzanilide; 2-methylbenzamide; 2-methylbenzoic acid; 2-hydroxymethylbenzoic acid; phthalide; and 2-carboxybenzaldehyde. The results indicate that initially hydroxylation of mepronil occurs on the four positions, followed by further oxidation, hydrolysis, cyclization or cleavage.
\end{abstract}

\section{INTRODUCTION}

Mepronil (3'-isopropoxy-2-methylbenzanilide) or Basitac $^{\circledR}$, the name registered by Kumiai Chemical Industry Co., is a new fungicide which has strong fungicidal activity against rice sheath blight fungus in particular. In previous papers the degradation of mepronil in soils ${ }^{1)}$ and plants ${ }^{2)}$ was reported. In this report results of an investigation on the degradation of ${ }^{14} \mathrm{C}$-mepronil exposed to sunlight and ultraviolet rays are given as a part of the evaluation of the ecotoxicological safety of mepronil.

\section{MATERIALS AND METHODS}

\section{Chemicals}

Two ${ }^{14} \mathrm{C}$-mepronil preparations, [aniline- $U$ $\left.{ }^{14} \mathrm{C}\right]$ mepronil (specific activity, $2.72 \mathrm{mCi} / \mathrm{mmol}$ ) and $\left[\right.$ carbonyl- $\left.{ }^{14} \mathrm{C}\right]$ mepronil (specific activity, $3.45 \mathrm{mCi} / \mathrm{mmol}$ ) were used in these studies.

* Present address: KI Chemical Research Institute, Kumiai Chemical Industry Co., Ltd., Shimizu, Shizuoka 424, Japan
These were synthesized by the Tokyo College of Pharmacy (Hachioji, Tokyo), and their radiochemical purities were shown to be more than $99 \%$. Table 1 shows the structures and $R f$ values on thin-layer chromatography $(t l c)$ of mepronil-related compounds. These authentic compounds were purchased or prepared by the Chemical Research Institute, Kumiai Chemical Co., Ltd. (100 Shibukawa, Shimizu, Shizuoka 424, Japan). The properties of I, III, IV, VII, VIII, IX, XIII and XIV have been described in a previous paper. ${ }^{1)}$ Properties of other synthesized compounds are as follows:

Compound II, $\mathrm{mp} 73^{\circ} \mathrm{C}$; IR $v \mathrm{~cm}^{-1}(\mathrm{KBr})$ : 1,500 (CO), 1,590, 1,500 (phenyl). Compound $\mathrm{V}, \mathrm{mp} 111-113^{\circ} \mathrm{C}$; bp $263^{\circ} \mathrm{C}$. Compound VI, $\mathrm{mp} 161-162^{\circ} \mathrm{C}$; $\mathrm{NMR}\left(\mathrm{CD}_{3} \mathrm{COCD}_{3}\right) \delta: 1.34(6 \mathrm{H}$, d $J=6 \mathrm{~Hz}), 4.65(1 \mathrm{H}, \mathrm{m} J=6 \mathrm{~Hz}), 6.95-7.10$ (3H, m arom.), $7.66(1 \mathrm{H}, \mathrm{s}), 7.90(4 \mathrm{H}, \mathrm{s}$ arom.); $\operatorname{IR} \nu \mathrm{cm}^{-1}(\mathrm{KBr}): 3,430(\mathrm{OH}), 1,700(\mathrm{CO}), 1,610$, 1,510 (phenyl). Compound $\mathrm{X}, \mathrm{mp} 141-142^{\circ} \mathrm{C}$; $\mathrm{NMR}\left(\mathrm{CD}_{3} \mathrm{COCD}_{3}\right) \delta: 2.47 \quad(3 \mathrm{H}, \mathrm{s}), \quad 6.17-8.33$ $\left(6 \mathrm{H}, \mathrm{m}\right.$ arom. $\left.\& \mathrm{NH}_{2}\right) ; \mathrm{IR} v \mathrm{~cm}^{-1}(\mathrm{KBr}): 3,380$, 1,190 $\left(\mathrm{NH}_{2}\right), 1,610,1,490$ (phenyl), 1,645 (CO). Compound XI, mp $92-93^{\circ} \mathrm{C}$; IR $\nu \mathrm{cm}^{-1}(\mathrm{KBr})$ : 
Table $1 R f$ values of mepronil and related compounds.

\begin{tabular}{|c|c|c|c|c|}
\hline \multirow{2}{*}{ No. } & \multirow{2}{*}{ Compound } & \multicolumn{3}{|c|}{ Solvent systems ${ }^{a}$ ) } \\
\hline & & A & B & $\mathrm{C}$ \\
\hline $\mathrm{I}$ & Mepronil: 3'-Isopropoxy-2-methylbenzanilide & 0.79 & 0.77 & 0.87 \\
\hline II & Phthalide & 0.67 & 0.77 & 0.79 \\
\hline III & 1-Hydroxy-3-oxo-2-(3'-isopropoxyphenyl)isoindoline & 0.70 & 0.53 & 0.56 \\
\hline IV & 3'-Isopropoxy-4'-hydroxy-2-methylbenzanilide & 0.65 & 0.48 & 0.72 \\
\hline $\mathrm{V}$ & 2-Methylbenzoic acid (o-toluic acid) & 0.76 & 0.15 & 0.46 \\
\hline VI & $N$-(3-Isopropoxy-4-hydroxyphenyl)phthalimide & 0.48 & 0.82 & - \\
\hline VII & 3'-Isopropoxy-2-hydroxymethylbenzanilide & 0.45 & 0.27 & 0.49 \\
\hline VIII & 3'-Hydroxy-2-methylbenzanilide & 0.36 & 0.19 & 0.40 \\
\hline IX & $3^{\prime}-(1-$ Hydroxymethylethoxy)-2-methylbenzanilide & 0.32 & 0.22 & 0.25 \\
\hline $\mathrm{X}$ & 2-Methylbenzamide (o-toluamide) & 0.30 & 0.19 & - \\
\hline $\mathrm{XI}$ & 2-Carboxybenzaldehyde & 0.26 & 0.13 & 0.14 \\
\hline $\mathrm{XII}$ & 2-Hydroxymethylbenzoic acid & 0.21 & 0.06 & 0.06 \\
\hline XIII & $3^{\prime}, 4^{\prime}-$ Dihydroxy-2-methylbenzanilide & 0.18 & 0.11 & - \\
\hline XIV & $3^{\prime}-(1-$ Carboxyethoxy $)-2-$ methylbenzanilide & 0.08 & 0.04 & 0.03 \\
\hline $\mathrm{XV}$ & Phthalic acid & 0.02 & 0 & 0 \\
\hline
\end{tabular}

a) A: $n$-hexane/dioxane (2/1), B: benzene/methanol (19/1), C: chloroform/ethyl acetate (5/1).

$3,500-3,000 \quad(\mathrm{COOH}), \quad 1,760 \quad(\mathrm{COOH}), \quad 1,730$ (CHO), 1,600, 1,470 (phenyl). Compound XII, $\mathrm{mp} 136^{\circ} \mathrm{C} ; \mathrm{NMR}\left(\mathrm{CD}_{3} \mathrm{COCD}_{3}\right) \delta: 4.79(2 \mathrm{H}, \mathrm{s})$, $5.77-8.67$ (6H, m arom.); $\mathrm{IR} \nu \mathrm{cm}^{-1}(\mathrm{KBr})$ : $3,450-2,500(\mathrm{COOH} \& \mathrm{OH})$.

\section{Exposure of ${ }^{14} \mathrm{C}$-Mepronil to Sunlight on Silica Gel Chromatoplate}

A mixture of [aniline-U- ${ }^{14} \mathrm{C}$ ] mepronil (20.9 $\mu \mathrm{g}, 0.21 \mu \mathrm{Ci})$ and unlabeled mepronil $(80 \mu \mathrm{g})$ was dissolved in $0.5 \mathrm{ml}$ of methanol. [Carbonyl${ }^{14} \mathrm{C}$ ] mepronil $(31.8 \mu \mathrm{g}, 0.41 \mu \mathrm{Ci})$ was dissolved in $0.5 \mathrm{ml}$ of methanol. When needed, [aniline$\mathrm{U}-{ }^{14} \mathrm{C}$ ] mepronil and [carbonyl $-{ }^{14} \mathrm{C}$ ]mepronil were mixed with photosensitizer xanthone 3.6 and 2.3 times respectively in $0.5 \mathrm{ml}$ of methanol. Each sample was spotted on a corner of a twodimensional $t l c$ plate; the plate was then covered with a thin film of polychlorovinylidene and exposed to sunlight for a prescribed period of time.

For preparing a larger amount of photoproducts, an acetone solution of unlabeled mepronil $(15 \mathrm{mg})$ and xanthone $(15 \mathrm{mg})$ was spotted on the plates and, after exposure to sunlight for 20 days, each photoproduct was separated by $t l c$.

\section{Irradiation with Ultraviolet Rays in Water}

In a $300 \mathrm{ml}$ irradiation vessel, $1.03 \mathrm{ppm}$ of mepronil ([aniline-U- $\left.-{ }^{14} \mathrm{C}\right]$ mepronil, $0.16 \mathrm{mg}$, $1.62 \mu \mathrm{Ci}$ and unlabeled mepronil, $0.15 \mathrm{mg}$ ) were dissolved in $300 \mathrm{ml}$ of distilled water and irradiated by a high-pressure mercury lamp with a maximum intensity of $365 \mathrm{~nm}$ (Riko Kagaku Sangyo Model UVL-100-300P, $100 \mathrm{~W}$ ) at $30^{\circ} \mathrm{C}$ for a prescribed time. [Carbonyl $-{ }^{14} \mathrm{C}$ ]mepronil $(0.22 \mathrm{mg}, \quad 2.83 \mu \mathrm{Ci})$ mixed with unlabeled mepronil $(0.15 \mathrm{mg})$ was dissolved in $300 \mathrm{ml}$ of distilled water $(1.23 \mathrm{ppm})$ and irradiated at $20^{\circ} \mathrm{C} ; 20$ or $30 \mathrm{ml}$ of the solution was extracted three times using $50 \mathrm{ml}$ of dichloromethane each time. The dichloromethane extract was concentrated and a portion of it was spotted on a chromatoplate.

For preparing a larger amount of the photoproducts, an aqueous solution (1.5 ppm) of unlabeled mepronil $(0.5 \mathrm{mg})$ was irradiated at $30^{\circ} \mathrm{C}$ for 7 days. Photoproducts after extraction with dichloromethane were separated by $t l c$.

\section{Thin-layer Chromatography and Autoradio- graphy}

A silica gel 60 chromatoplate (without fluorescent indicator, precoated, $20 \times 20 \mathrm{~cm}$, $0.25 \mathrm{~mm}$ thickness, E. Merck) was used for exposure to sunlight, and silica gel $60 \mathrm{~F}_{254}$ (with fluorescent indicator, precoated, $20 \times 20 \mathrm{~cm}$. $0.25 \mathrm{~mm}$ thickness, E. Merck) was used for 
purification and identification. Several solvent systems were examined; three of these are shown in Table 1. The plates were developed in two-dimensional ways, first with $n$-hexane/ dioxane (2/1) and secondly with benzene/ methanol (19/1). After having been developed and dried, the chromatoplates were contacted with X-ray film [Konishiroku Photo Ind. Xray film, JX $(10 \times 12) 25.4 \times 30.5 \mathrm{~cm}]$ for 7 days for preparation of the autoradiogram. Spots of unlabeled compounds were detected under ultraviolet lamp (254 nm).

\section{Radioassay}

One $\mathrm{ml}$ aliquot of the irradiated solution was dissolved with $12 \mathrm{ml}$ of hydrophilic scintillator (DPO $4.0 \mathrm{~g}$, POPOP $0.4 \mathrm{~g}$, naphthalene $100 \mathrm{~g}$, toluene $150 \mathrm{ml}$, ethyl cellosolve $100 \mathrm{ml}$, and dioxane $750 \mathrm{ml}$, to make $1,000 \mathrm{ml}$ ) and radioassayed using a liquid scintillation spectrometer (Aloka, Model LSC-502). The photoproducts were scraped off their chromatoplates with the silica gel and radioassayed as described above.

\section{Identification of Degradation Products}

The following methods were utilized for identification: The ${ }^{14} \mathrm{C}$-photoproducts were compared with reference compounds by cochromatography; ${ }^{14} \mathrm{C}$-photoproducts were methylated with diazomethane or reduced with sodium borohydride and then compared with the methylated or reduced reference compounds by cochromatography; ${ }^{14} \mathrm{C}$-photoproducts were hydrolyzed by refluxing with concentrated hydrochloric acid and the products were compared with reference compounds by cochromatography; gas chromatography-mass spectrometry (GC-MS) spectra of the unlabeled photoproducts were analyzed and compared with the spectra of reference compounds. A Shimadzu Model LKB-900 was used for the GC-MS. The operating conditions were as follows: column length, $2 \mathrm{~m}$; column packing, OV-1 $1.5 \% /$ Shimalite $\mathrm{W}$; flow rate of helium, $20 \mathrm{ml} / \mathrm{min}$; column temperature, $260^{\circ} \mathrm{C}$; injection temperature, $280^{\circ} \mathrm{C}$; ionizing energy, $20 \mathrm{eV}$ and $75 \mathrm{eV}$.

\section{RESULTS AND DISCUSSION}

1. Photoproducts from $\left[\right.$ Aniline $\left.-U-{ }^{14} C\right]$ and [Carbonyl $\left.-{ }^{14} \mathrm{C}\right]$ Mepronil

The photoproducts obtained by exposure to sunlight on silica gel chromatoplates and by irradiation with ultraviolet rays in water are referred to by LS- and LU-numbers, respectively. In Table 2 all products are indicated by an L-number, for example, LS--1 and $L U-1$ are $L-1$. With sunlight, twenty to thirty spots appeared on the autoradiogram from two ${ }^{14} \mathrm{C}$-mepronil preparations after exposure to sunlight for 20 days, among which rather distinct spots (LS-1 $\sim \mathrm{LS}-14)$ are shown in Fig. 1.

Over ten spots were common in photoproducts from [aniline- $\mathrm{U}-{ }^{14} \mathrm{C}$ ] and [carbonyl $-{ }^{14} \mathrm{C}$ ] mepronil; this would indicate that they retain the anilide-linkage. On the other hand, several photoproducts were detected from [carbonyl${ }^{14} \mathrm{C}$ ]mepronil alone which seem to be derived from only the $o$-toluic acid moiety. Photoproducts from [aniline-U-U $-{ }^{14} \mathrm{C}$ ]mepronil alone were not detected. LS-14 is a mixture of highpolar substances remaining at the $t l c$ origin, from which several substances $(\mathrm{L}-14 \mathrm{a} \sim \mathrm{d})$ were obtained by methylation with diazomethane. The identification or characterization of the photoproducts are summarized in Table 2. Two unknowns were characterized by GCMS, though not identified: LS-3 (UK-1), $m / z 297\left(\mathrm{M}^{+}\right.$base peak), 255, 240, 224, and LS-4 (UK-2), m/z $267\left(\mathrm{M}^{+}\right), 225$ (base peak).

Figure 2 shows the autoradiograms from two ${ }^{14} \mathrm{C}$-mepronil preparations irradiated with ultraviolet rays in water for 80 hours. Three spots (LU-1, LU-6 and LU-10) were found to be common to both ${ }^{14} \mathrm{C}$-mepronils, indicating that these products retain the anilide-linkage. On the other hand, three spots (LU-2, LU-5 and LU-12) were detected from - [carbonyl${ }^{14} \mathrm{C}$ ]mepronil alone, indicating that these were cleaved photoproducts with only an o-toluic acid-derived moiety. Photoproducts originating from [aniline- $\mathrm{U}-{ }^{14} \mathrm{C}$ ]mepronil alone were not detected. Results of the identification are also shown in Table 2.

\section{Fates of Mepronil and its Photoproducts}

In Fig. 3 results are shown of the degrada- 
Table 2 Identification and $R f$ values of photoproducts produced with sunlight and UV lamp.

\begin{tabular}{|c|c|c|c|c|c|}
\hline \multirow{2}{*}{ Products } & \multicolumn{2}{|c|}{ Characterized or identified } & \multicolumn{3}{|c|}{ Solvent systems ${ }^{\mathrm{c}}$} \\
\hline & as & by & $\mathrm{A}$ & $\mathrm{B}$ & $\mathrm{C}$ \\
\hline $\mathrm{L}-1$ & $\mathrm{I}$ & $(1)(2)$ & 0.79 & 0.77 & 0.87 \\
\hline 2 & II & $(1)(5)$ & 0.67 & 0.77 & 0.79 \\
\hline $3^{\text {a) }}$ & $\mathrm{UK}-1$ & (2) & 0.51 & 0.72 & - \\
\hline $4^{\text {a) }}$ & $\mathrm{UK}-2$ & $(2)$ & 0.68 & 0.52 & 一 \\
\hline $5^{b)}$ & $\mathrm{UK}-3$ & only from [carbonyl-14 $\mathrm{C}$ ]mepronil & 0.34 & 0.82 & 一 \\
\hline 6 & III & $(1)(2)(4)$ & 0.70 & 0.53 & 0.56 \\
\hline $7^{\text {a) }}$ & IV & $(1)(2)$ & 0.65 & 0.48 & 0.72 \\
\hline $8^{\text {a) }}$ & $\mathrm{V}$ & $(1)(3)$ & 0.76 & 0.15 & 0.46 \\
\hline $9^{\text {a) }}$ & VII & (1) & 0.45 & 0.27 & 0.49 \\
\hline 10 & VIII & $(1)(3)$ & 0.36 & 0.19 & 0.40 \\
\hline $11^{\text {a) }}$ & IX & (1) & 0.32 & 0.22 & 0.25 \\
\hline 12 & $\mathrm{X}$ & $(1)(2)(5)$ & 0.30 & 0.19 & - \\
\hline $13^{\mathrm{a})}$ & $\mathrm{UK}-4$ & only from [carbonyl- ${ }^{14} \mathrm{C}$ ]mepronil & 0.24 & 0.06 & - \\
\hline $14 a^{a)}$ & $\mathrm{XI}$ & $(1)(3)$ & 0.26 & 0.13 & 0.14 \\
\hline $14 b^{a)}$ & XII & $(1)(3)$ & 0.21 & 0.06 & 0.06 \\
\hline $14 c^{a)}$ & XIII & $(1)(3)$ & 0.18 & 0.11 & - \\
\hline $14 d^{a)}$ & XIV & (3) & 0.08 & 0.04 & 0.03 \\
\hline
\end{tabular}

(1) cochromatography, (2) GC-mass spectrometry, (3) methylation with $\mathrm{CH}_{2} \mathrm{~N}_{2}$ and cochromatography, (4) reduction with $\mathrm{NaBH}_{4}$ and cochromatography, (5) hydrolysis with conc. $\mathrm{HCl}$ aq. and cochromatography.

a) only from exposure to sunlight, b) only from irradiation with ultraviolet rays.

c) A: $n$-hexane/dioxane (2/1), B: benzene/methanol (19/1), C: chloroform/ethyl acetate (5/1). UK: unknowns.

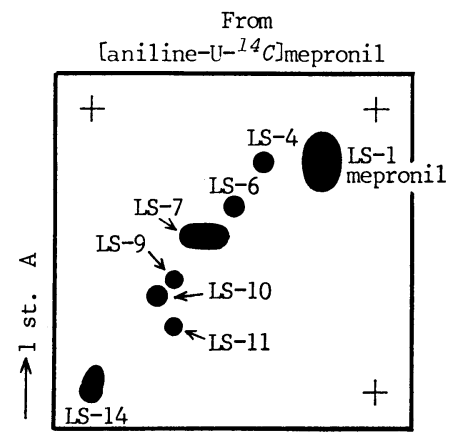

$\longrightarrow 2$ nd. B

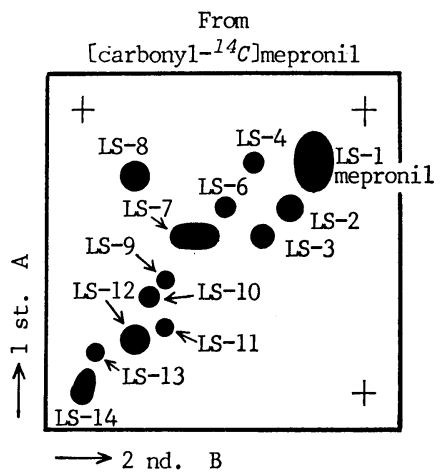

Fig. 1 Thin-layer autoradiograms of ${ }^{14} \mathrm{C}$-mepronil and its photoproducts on silica gel chromatoplates exposed to sunlight for 20 days.

Solvent system; A: $n$-hexane/dioxane (2/1), B: benzene/methanol (19/1).

tion with sunlight for 80 days (between Sept. 22, 1977 and Dec. 10, 1977) using [aniline-U- $-{ }^{14} C$ ] mepronil. The remaining mepronil during the period decreased from $84.8 \%$ (5 days after application) to $34.1 \%$ (80 days), $35.2 \%$ of the radioactivity was lost from the chromatoplates after 80 days. Radioactivity at the $t l c$ origin (LS-14) increased gradually to $21.5 \%$ after 80 days. The amounts of other identified or unknown products were not significant. With xanthone as a photosensitizer, degradation of mepronil was accelerated at the rate of 1.5-2 times. Results of degradation with sunlight for 80 days (between Nov. 16, 1977 

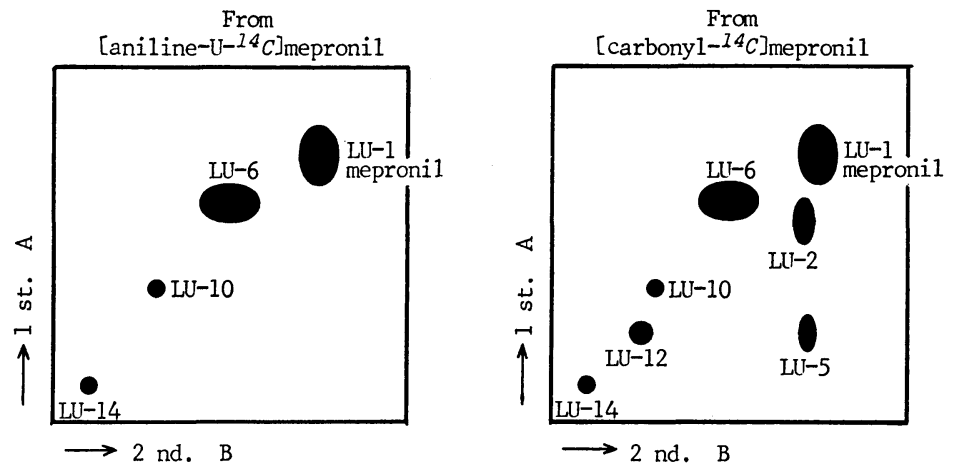

Fig. 2 Thin-layer autoradiograms of ${ }^{14} \mathrm{C}$-mepronil and its photoproducts in water irradiated with ultraviolet rays for 80 hours.

Solvent system; A: $n$-haxane/dioxane (2/1), B: benzene/methanol (19/1).
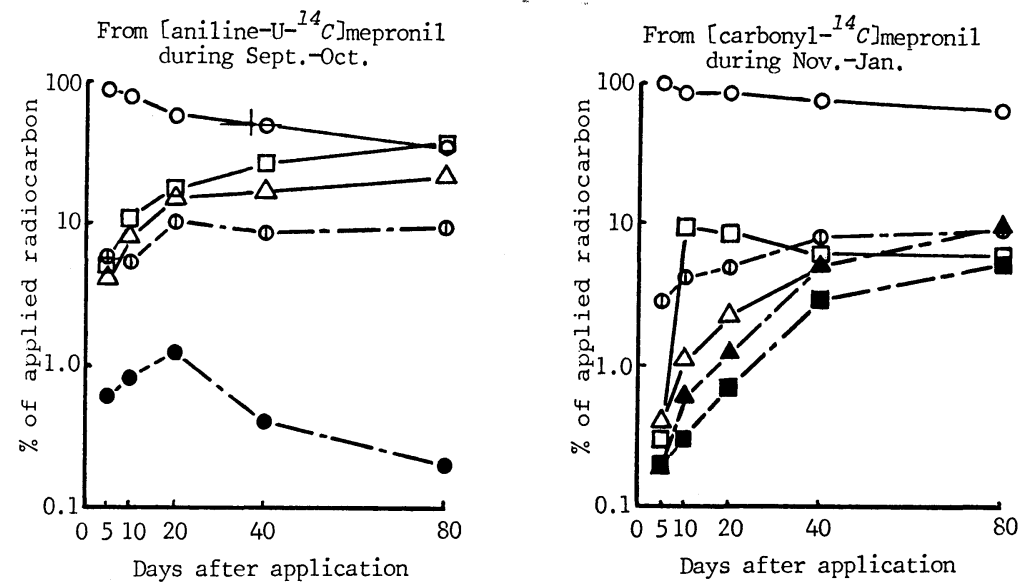

Fig. 3 Degradation of ${ }^{14} \mathrm{C}$-mepronil on silica gel chromatoplate exposed to sunlight.

○: LS-1 (mepronil), ๑: LS-7, $\mathbf{\square}:$ LS-8, $\Delta$ : LS-12, $\Delta$ : LS-14, $\square$ : Loss during exposure, (1): Others.

and Jan. 30, 1978) using [carbonyl $\left.-{ }^{14} C\right]$ mepronil are also shown in Fig. 3. The amount of remaining mepronil must be the same, though differently labeled in position, if the irradiation conditions are the same. However, the remaining mepronil during the period decreased from $96.1 \%$ (5 days after application) to $62.2 \%$ (80 days). Such difference between aniline- and carbonyl-labeled mepronils would be due to milder conditions applied on the carbonyl-labeled mepronil. Loss during exposure $(5.9 \%)$ and the radioactivity at the origin $(9.4 \%)$ were also lower. However, the greater loss of radioactivity from [aniline-U- $\left.{ }^{14} \mathrm{C}\right]$ mepronil seemed mostly attributable to the loss of aniline-derived products when they formed because such products were not observed, whereas the corresponding acidderived products were observed. Xanthone also increased photodegradation of [carbonyl$\left.{ }^{14} \mathrm{C}\right]$ mepronil.

From the plotted curve, the half-life of mepronil during exposure to sunlight is estimated as 36 days, (Sept.-Dec.). When mixed with xanthone, the half-life was shortened to 16.5 days. During exposure to sunlight during Nov.-Jan. a half-life was not estimated but with xanthone it was 48 days. 

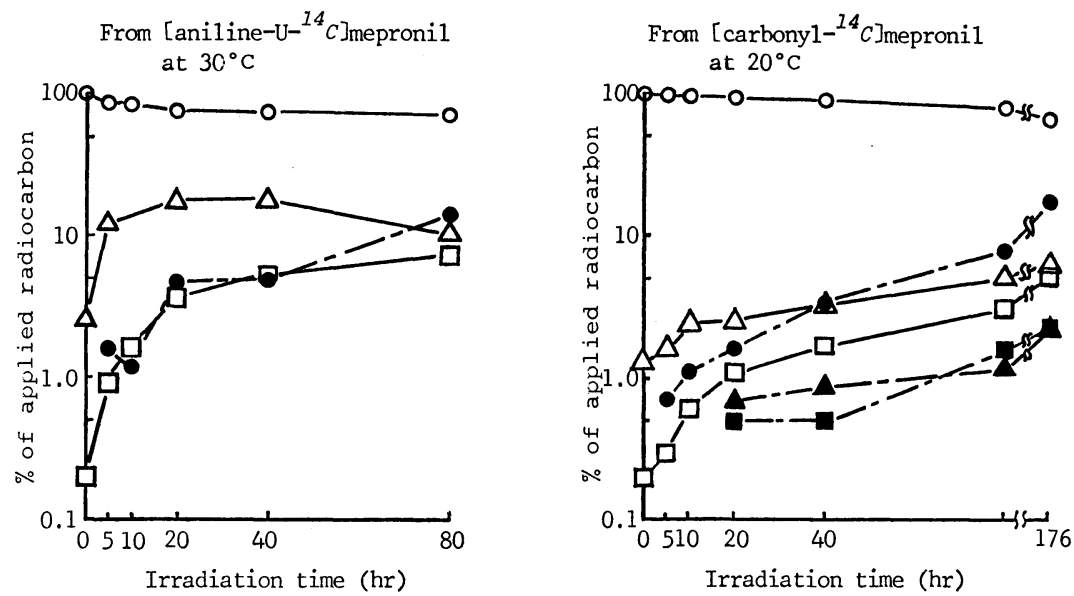

Fig. 4 Degradation of ${ }^{14} C$-mepronil in water irradiated by ultraviolet light.

O: LU-1 (mepronil), $\Delta$ : LU-2, ㅁ: LU-5, ๑: LU-6, $\Delta$ : Others, $\square$ : Unextractable $\left(\mathrm{H}_{2} \mathrm{O}\right)$.

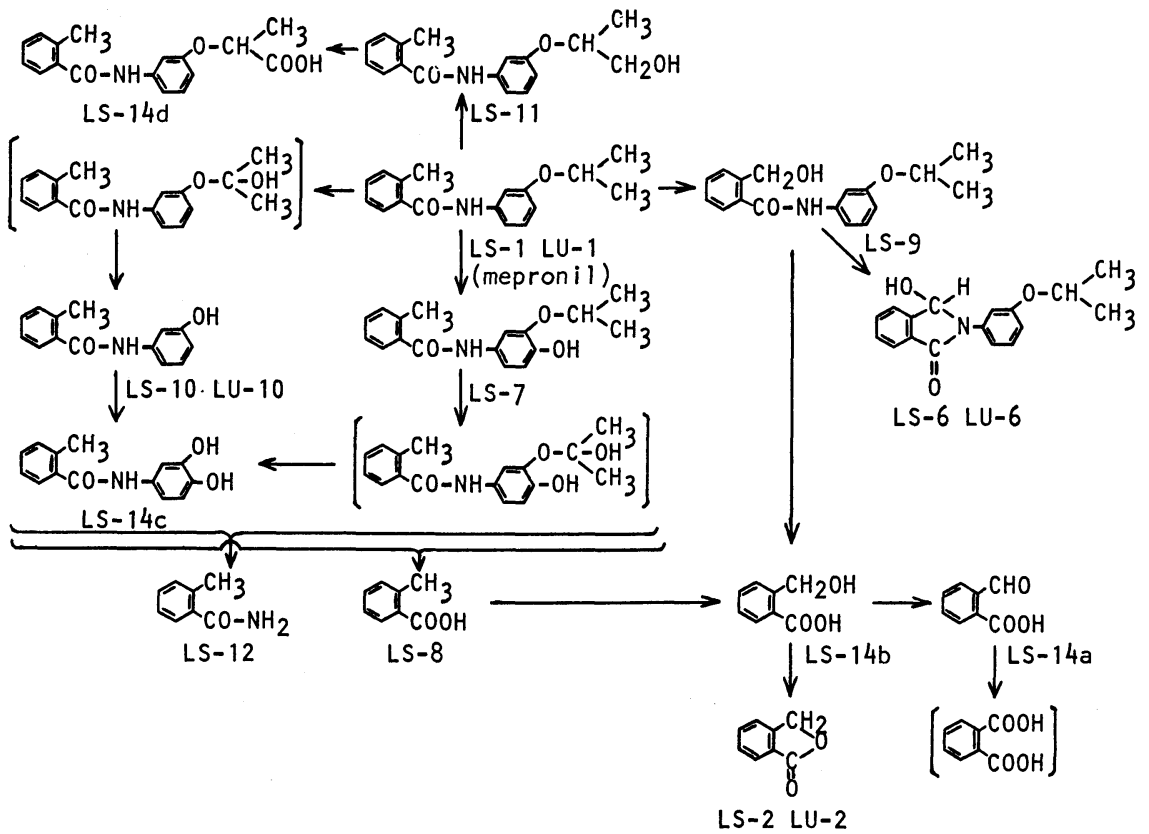

Fig. 5 Proposed photodegradation pathways for mepronil.

Degradation in water with ultraviolet rays was slow, as shown in Fig. 4. As noted by the difference of remaining mepronil for anilineand carbonyl-labeled mepronil $(68.0 \%$ and $81.1 \%$ respectively, after 80 hours) the temperature effect has been significant. Formation of LU-6 was remarkable. The radioactivity remained in the aqueous layer after dichloromethane extraction (unextractable) increased slightly during irradiation, but no organic-soluble products were obtained by methylation.

No half-life of mepronil in water by irradiation with ultraviolet rays was estimated. In brief, mepronil is rather photostable under both conditions tested. 


\section{Proposed Photodegradation Pathways for Mepronil}

The interrelationship among the identified photoproducts is illustrated in Fig. 5. Though mepronil is rather stable, hydroxylation occurs at four positions. The product hydroxylated at methyl group on the acid moiety (L-9) is further converted to 1-hydroxy-3-oxo-2-(3'isopropoxyphenyl)isoindoline $(\mathrm{L}-6)$ by oxidation-cyclization. This product seems to be a terminal product as further irradiation under the conditions stated did not change it. The intermediate (not identified) hydroxylated at the center carbon of the isopropoxy group on the aniline moiety is unstable and degraded to 3'-hydroxy-2-methylbenzanilide (L-10). Hydroxylation also occurs at the terminal carbon of the isopropoxy group giving 3'-(1-hydroxymethylethoxy)-2-methylbenzanilide (L-11), which is further oxidized to give $3^{\prime}-(1-$ carboxyethoxy)-2-methylbenzanilide (L-14d). Hydroxylation at the para position to the amide of aniline moiety gives 3 '-isopropoxy-4'-hydrox$\mathrm{y}-2-$ methylbenzanilide (L-7). Combinations of these changes give further products, such as $3^{\prime}, 4^{\prime}$-dihydroxy-2-methylbenzanilide (L14c). As shown in Fig. 3, LS-8 (o-toluic acid) and LS-12 (o-toluamide) appeared from quite early stages during exposure to sunlight and were the major products. The mechanism of the formation of $o$-toluamide is interesting to study. It may require cleavage between aminonitrogen and phenyl-carbon or amidation of $o$-toluic acid. This work will be reported elsewhere.

\section{ACKNOWLEDGEMENTS}

The authors wish to express their thanks to Prof. Shigeru Inaba and other members of the Radioisotope Research Institute, Tokyo University of
Agriculture, for their kind suggestions and also to Prof. Shigeo Baba, Tokyo College of Pharmacy, for the supply of radioactive mepronil. Thanks are also due to Dr. Hironari Sugiyama and Dr. Isao Shimazaki of KI Chemical Research Institute for the supply of non-radioactive chemicals and to Mr. Tadaharu Kitagaki, Mr. Rokuro Shinohara and Mr. Yuzuru Asano of Life Science Research Institute, Kumiai Chemical Co., Ltd., for their valuable advice and GC-MS analyses on this study.

\section{REFERENCES}

1) T. Yumita \& I. Yamamoto: J. Pesticide Sci. 5, 363 (1980)

2) T. Yumita, A. Shoji \& I. Yamamoto: $J$. Pesticide Sci. 6, 347 (1981)

\section{要 約}

\section{メプロニルの光分解}

弓田隆司, 山本 出

メプロニルの〔アニリン環-14 $C$ 〕および〔カルボニルー $\left.{ }^{14} C\right]$ 標識体を用い, $t l c$ 上太陽光に 80 日間あてた結果, 季節によりメプロニルの残留量は異なり， $34.1 \%(9$ ～ 12 月), $62.2 \%$ (11月〜翌 1 月）であった. 半減期は 9 12 月の間で 36 日, 光増感剤キサントンを加えると 16.5 日であった. 水中紫外光による分解は抗々く, $30^{\circ} \mathrm{C}, 80$ 時間で $32 \%$ であった. 光分解物として次の 12 化合物が同定された：3'-(1-hydroxymethylethoxy)-2methylbenzanilide, 3'-isopropoxy-2-hydroxymethylbenzanilide, $3^{\prime}$-isopropoxy - 4'-hydroxy-2-methylbenzanilide, 3'-hydroxy-2-methylbenzanilide, 1hydroxy-3-oxo-2-(3'-isopropoxyphenyl)isoindoline, $3^{\prime}-\left(1\right.$ - carboxyethoxy) -2-methylbenzanilide, $3^{\prime}, 4^{\prime}-$ dihydroxy-2-methylbenzanilide, 2-methylbenzamide, 2-methylbenzoic acid, 2-hydroxymethylbenzoic acid, phthalide, 2-carboxybenzaldehyde. これらの分解物 は, メプロニルが 4 力所で酸化, 加水分解, 環化および 開裂などの変化をうけたものと思われる. 